\title{
Growth and Yield of Cotton as Influenced by Planting Geometry and Genotypes under High Density Planting System
}

\author{
C. Shashi Kumar* and C. Ramachandra
}

Department of Agronomy, College of Agriculture, UAS, GKVK, Bengaluru-560065, India

*Corresponding author

\begin{tabular}{|l|}
\hline Ke y w o r d s \\
planting geometry, \\
Genotypes, Boll \\
weight, \\
Monopodial, \\
sympodial, Seed \\
cotton yield
\end{tabular}

\section{Keywords}

planting geometry,

Genotypes, Boll

weight,

sympodial, Seed

cotton yield

Article Info

Accepted:

Available Online

\section{A B S T R A C T}

A field experiment was conducted at Krishi Vigyan Kendra, Chamarajanagar, University of Agriculture Sciences, GKVK, Bengaluru during Kharif 2016 to develop suitable planting geometry and genotypes for high density planting system of cotton in medium black cotton soil under Southern Dry Zone of Karnataka. The experiment was laid out in split plot design consisting of fifteen treatment combinations involving five planting geometry and three genotypes. The growth and yield of cotton differed significantly due to planting geometry and genotypes under high density planting system. The results of the study revealed that among planting geometry, spacing at $45 \times 10 \mathrm{~cm}$ recorded significantly taller plant $(95.76 \mathrm{~cm})$, Leaf area index at 90 DAS (3.26) and higher seed cotton yield (1589 kg ha 1), whereas planting geometry at $90 \times 60 \mathrm{~cm}$ resulted higher dry-matter accumulation per plant (149.98 g plant-1), more number of monopodial branches (1.32 plant-1), sympodial branches (16.50 plant-1), more number of bolls per plant (17.83), boll weight $(3.36 \mathrm{~g})$ compared to other treatments in the study. Among genotypes tested under different planting geometry DSC-99 produced taller plant $(91.14 \mathrm{~cm})$, higher dry-matter accumulation (141.39 g plant-1), more number of monopodial branches (2.90 plant-1), sympodial branches (12.48 plant-1), more number of bolls per plant (14.68), boll weight (3.21 g) compared to ARBC and Suraj genotypes.

\section{Introduction}

Cotton is one of the principal fibre crop of India and popularly known as white gold. It occupies a prominent role in Indian farming and national economy. In India cotton is cultivated in an area of 122 lakh hectare with a production of 377 lakh bales and productivity of $524 \mathrm{~kg}$ lint ha ${ }^{-1}$ (Anon., 2017). The productivity of the cotton depends on several factors, among them adoption of suitable planting geometry with selection of high yielding genotypes plays an important role in enhancing the productivity of the cotton.

High density planting system (HDPS) is generally referred as planting at closer spacing than the recommended spacing with a sole objective of maximizing the yield per unit area and it varies from genotype to genotype. In Brazil higher productivity was achieved through development of compact genotypes suited for high density planting 
geometry which enables to accommodate a plant population of 1.5 to 2.5 lakh plants $\mathrm{ha}^{-1}$ with 8-14 bolls per plant at a single boll weight of $4.0 \mathrm{~g}$, thereby achieving higher seed cotton yield (45 to $55 \mathrm{q} \mathrm{ha}^{-1}$ ). Major cotton growing countries like USA, Australia, Uzbekistan and China have developed suitable plant types to accommodate plant densities varying from 1-2.5 lakh plants $\mathrm{ha}^{-1}$ through narrow row spacing. The availability of compact genotypes, better pest management strategies, shortage of labour for picking, benefits of growth regulators (retardants and defoliants) and above all success of mechanical pickers have made HDPS successful in above countries.

The Southern dry zone (Zone-6) of Karnataka comprises the districts of Mysore and Chamarajanagar, where $\mathrm{Bt}$ cotton is extensively grown under rainfed situation. Despite the saturation of the Bt cotton hybrids in the region, the productivity is quite low because of boll formation and boll development stages coincides with terminal drought resulting in low yields.

In addition, cotton producers are presently facing the problems of rising production costs and static or declining returns from cotton. To combat these problems, one of the viable option is growing cotton in reduced row spacing and increased plant populations. Closer row spacing's and higher plant populations under HDPS also lead to more rapid canopy closure than conventionally spaced cotton.

Rapid canopy closure, in turn leads to reduced weed competition increased light interception and potentially decreased soil water evaporation. Keeping these points in view the present study on growth and yield of cotton as influenced by planting geometry and genotypes under high density planting system (HDPS) was undertaken.

\section{Materials and Methods}

A field experiment was conducted at Krishi Vigyan Kendra, Chamarajanagar during kharif season of 2016, which is situated in the Southern Dry Zone (Zone-6) of Karnataka. The soil of the experimental site is medium black soil with low in organic carbon content $(0.23 \%)$, low in available nitrogen (214.6 $\mathrm{kg} / \mathrm{ha}$ ), medium in available phosphorous $(22.3 \mathrm{~kg} / \mathrm{ha})$ and high in available potassium (293.8 kg/ha).

The annual rainfall received during the cropping season was $272.0 \mathrm{~mm}$. The experiment was laid out in split plot design and replicated thrice. The experiment consists of 15 treatment combinations comprising five planting geometries $\left(\mathrm{P}_{1} ; 45 \times 10 \mathrm{~cm}, \mathrm{P}_{2:} 45\right.$ $\mathrm{X} 20 \mathrm{~cm}, \mathrm{P}_{3}: 60 \mathrm{X} 10 \mathrm{~cm}, \mathrm{P}_{4}: 60 \mathrm{X} 10 \mathrm{~cm}, \mathrm{P}_{5}: 90$ $X 60 \mathrm{~cm}$ (planting densities of 222222, 111111, 166666, 83333 and 18518 plants/ha, respectively) in main plots and three cotton genotypes $\left(\mathrm{V}_{1}\right.$ :DSC-99, $\mathrm{V}_{2}$ :ARBC-64 and $\mathrm{V}_{3}$ :Suraj) as subplots. The field was laid out as per the plan of layout and plots were marked. Furrows were opened at prescribed geometries and one or two seeds were dibbled within the row as per the treatment details.

All the recommended agronomic practices and timely need based plant protection measures were followed for raising healthy crop. The growth and yield observations such as plant height $(\mathrm{cm})$, dry matter accumulation (g/plant), monopodial branches /plant, sympodial branches/plant, number of bolls/plant, single boll weight (g) and seed cotton yield $(\mathrm{kg} / \mathrm{ha})$ were recorded as per the standard procedure.

The data was statistically analyzed by adopting standard statistical techniques of analysis of variance by Gomez and Gomez (1984). 


\section{Results and Discussion}

\section{Effect of cotton genotypes and planting geometries on growth attributes}

The growth parameters of the cotton were significantly influenced by planting geometry and genotypes (Table 1). Among the cotton genotypes evaluated under different geometry DSC-99 recorded significantly taller plants $(91.14 \mathrm{~cm})$, leaf area index (2.90), dry matter accumulation $\left(141.39 \mathrm{~g} \mathrm{plant}^{-1}\right)$ monopodial branches $\left(0.90\right.$ plant $\left.^{-1}\right)$ and sympodial branches (12.48 plant $\left.^{-1}\right)$ over the national check Suraj $(88.09 \mathrm{~cm}, 1.43,132.54 \mathrm{~g}, 1.01$ and 10.47, respectively). The higher growth parameters of cotton genotypes might be due to the reason that the higher ability of genotypes in harnessing the solar energy and converting it into biomass. Similar findings were also reported by Jaffar et al., (2017).

Among planting geometry, spacing at $45 \times 10$ $\mathrm{cm}$ recorded taller plant $(95.76 \mathrm{~cm})$ and higher leaf area index (1.79) followed by spacing at $60 \times 10 \mathrm{~cm}(94.43 \mathrm{~cm}$ and 1.73 respectively). Whereas, significantly lower plant height $(82.61 \mathrm{~cm})$ and leaf area index at 90 DAS (3.26) was recorded at spacing of 90 $\mathrm{X} 60 \mathrm{~cm}$. This might be due to more number of plants per unit area produced more height per plant which may be due to the increased competition for sunlight and $\mathrm{CO}_{2}$. These results are in accordance with Sisodia and Khamparia (2007)

Wider spacing at $90 \times 60 \mathrm{~cm}$ recorded significantly higher monopodial branches (1.58 plant $\left.^{-1}\right)$, sympodial branches (16.50 plant $\left.^{-1}\right)$ and dry matter accumulation (149.98 plant $^{-1} \mathrm{~g}$ ) as compared to planting geometry of $45 \times 10 \mathrm{~cm}, 45 \times 20 \mathrm{~cm}, 60 \times 10 \mathrm{~cm}$ and $60 \times$ $20 \mathrm{~cm}$.

The increase in dry matter accumulation per plant, more number of sympodial and monopodial branches per plant at wider spacing is mainly due to the larger ground area, more availability of moisture and nutrients, more light interception by more number of leaves and leaf area resulting in higher photosynthetic activity and more biomass accumulation through the process of plant metabolism. These results are in conformity with Bhalerao et al., (2008). The interaction effect between planting geometry and genotypes was found non-significant.

\section{Effect of planting geometry and cotton genotypes on yield and yield attributes}

The yield and yield components of cotton differed significantly due to planting geometry and genotypes (Table 2). Wider spacing at $90 \times 60 \mathrm{~cm}$ recorded significantly more number of bolls per plant (17.83), boll weight (3.36 $\left.\mathrm{g} \mathrm{boll}^{-1}\right)$ and higher seed cotton yield $\left(57.27 \mathrm{~g}\right.$ plant $\left.^{-1}\right)$ Whereas, closer spacing at $45 \times 10 \mathrm{~cm}$ recorded significantly higher seed cotton yield of $1589 \mathrm{~kg} \mathrm{ha}^{-1}$ with lesser number of bolls per plant (8.60), boll weight $\left(2.63 \mathrm{~g} \mathrm{boll}^{-1}\right)$ followed by spacing at $60 \times 10 \mathrm{~cm}$.

The planting geometry of $45 \times 10 \mathrm{~cm}$ and 60 $X 10 \mathrm{~cm}$ recorded on par results with respect to boll weight $\left(2.63 \mathrm{~g}\right.$ and $2.84 \mathrm{~g} \mathrm{boll}^{-1}$, respectively) and seed cotton yield per hectare (1589 and $1451 \mathrm{kgha}^{-1}$, respectively) and found significantly superior over other treatments. The increase in seed cotton yield in closer spacing was due to higher plant population per unit area. In comparison to higher plant density the lower plant density recorded more number of bolls and yield plant $^{-1}$ but higher plant population, which compensated the yield plant ${ }^{-1}$ even though there were lesser number of bolls and yield plant $^{-1}$. Lower plant population is the major cause for its low seed cotton yield. These results are in line with Pawar et al., (2010) 
Table.1 Growth attributes of cotton as influenced by genotypes and planting geometry under high density planting

\begin{tabular}{|c|c|c|c|c|c|c|}
\hline Treatments & $\begin{array}{c}\text { Plant } \\
\text { density } \\
\text { (No./ha) }\end{array}$ & $\begin{array}{l}\text { Plant height at } \\
\text { harvest }(\mathbf{c m})\end{array}$ & $\begin{array}{c}\text { Leaf area } \\
\text { Index at } 90 \\
\text { DAS }\end{array}$ & $\begin{array}{c}\text { Dry matter } \\
\text { production at } \\
\text { Harvest (g/plant) }\end{array}$ & $\begin{array}{c}\text { Monopodial } \\
\text { branches/ } \\
\text { Plant at } 90 \\
\text { DAS }\end{array}$ & $\begin{array}{c}\text { Sympodial } \\
\text { branches/ } \\
\text { Plant at } \\
\text { harvest }\end{array}$ \\
\hline \multicolumn{7}{|c|}{ Main Plot: Planting Geometry (P) } \\
\hline$P_{1}-45 X 10$ & $2,22,222$ & 95.76 & 3.26 & 119.94 & 0.53 & 8.23 \\
\hline$P_{2^{-}}-45 X 20$ & $1,11,111$ & 88.86 & 2.77 & 133.97 & 0.71 & 11.47 \\
\hline$P_{3}-60 X 10$ & $1,66,666$ & 94.43 & 2.98 & 132.34 & 0.71 & 9.29 \\
\hline$P_{4}-60 \times 20$ & 83,333 & 85.11 & 2.65 & 146.13 & 0.91 & 11.63 \\
\hline$P_{5}-90 \times 60$ & 18,518 & 82.61 & 1.96 & 149.98 & 1.32 & 16.50 \\
\hline SEm \pm & & 0.37 & 0.14 & 2.27 & 0.03 & 0.55 \\
\hline CD at $5 \%$ & & 1.20 & 0.46 & 7.40 & 0.08 & 1.81 \\
\hline \multicolumn{7}{|c|}{ Sub Plot: Genotypes (V) } \\
\hline$V_{1}-$ DCS-99 & & 91.14 & 2.90 & 141.39 & 0.90 & 12.48 \\
\hline$V_{2}$-ARBC-64 & & 88.83 & 2.73 & 135.49 & 0.83 & 11.32 \\
\hline V $_{3^{-}}$SURAJ & & 88.09 & 2.54 & 132.54 & 0.77 & 10.47 \\
\hline SEm \pm & & 0.57 & 0.09 & 1.60 & 0.03 & 0.38 \\
\hline CD at $5 \%$ & & 1.68 & 0.27 & 4.71 & 0.10 & 1.13 \\
\hline \multicolumn{7}{|c|}{ Interaction: Planting Geometry X Genotypes } \\
\hline SEm \pm & & 1.27 & 0.20 & 0.98 & 0.10 & 0.85 \\
\hline CD at $5 \%$ & & NS & NS & NS & NS & NS \\
\hline
\end{tabular}

Table.2 Yield and yield attributes of cotton as influenced by genotypes and planting geometry under high density planting

\begin{tabular}{|c|c|c|c|c|c|c|}
\hline Treatments & $\begin{array}{l}\text { Plant } \\
\text { Density } \\
\text { (No./ha) }\end{array}$ & $\begin{array}{c}\text { No. of bolls } \\
\text { /plant }\end{array}$ & $\begin{array}{c}\text { No. of } \\
\text { Bolls } / \mathrm{m}^{2}\end{array}$ & $\begin{array}{c}\text { Boll } \\
\text { weight (g) }\end{array}$ & $\begin{array}{c}\text { Seed } \\
\text { Cotton } \\
\text { yield } \\
\text { (g/plant) }\end{array}$ & $\begin{array}{l}\text { Seed Cotton } \\
\text { Yield (kg/ha) }\end{array}$ \\
\hline \multicolumn{7}{|c|}{ Main Plot: Planting Geometry (P) } \\
\hline$P_{1^{-}}$45X10 & $2,22,222$ & 8.60 & 189.2 & 2.63 & 17.89 & 1589 \\
\hline$P_{2^{-}}-45 \times 20$ & $1,11,111$ & 12.50 & 137.5 & 3.04 & 33.32 & 1367 \\
\hline$P_{3^{-}} 60 \times 10$ & $1,66,666$ & 11.13 & 178.1 & 2.84 & 26.93 & 1451 \\
\hline$P_{4^{-}} 60 \times 20$ & 83,333 & 15.33 & 122.7 & 3.21 & 44.97 & 1255 \\
\hline$P_{5} 90 \times 60$ & 18,518 & 17.83 & 35.7 & 3.36 & 55.91 & 999 \\
\hline SEm \pm & & 0.67 & 6.0 & 0.10 & 3.75 & 57.92 \\
\hline CD at $5 \%$ & & 2.20 & 19.7 & 0.32 & 12.21 & 188.8 \\
\hline \multicolumn{7}{|c|}{ Sub Plot: Varieties (V) } \\
\hline$V_{1}$-DCS-99 & & 14.68 & 150.9 & 3.21 & 43.53 & 1383 \\
\hline$V_{2}$-ARBC-64 & & 12.78 & 130.2 & 2.99 & 34.36 & 1328 \\
\hline V $_{3^{-}}$SURAJ & & 11.78 & 116.9 & 2.84 & 29.52 & 1286 \\
\hline SEm \pm & & 0.58 & 5.4 & 0.07 & 2.92 & 24.19 \\
\hline CD at $5 \%$ & & 1.72 & 15.9 & 0.21 & 8.63 & 71.36 \\
\hline \multicolumn{7}{|c|}{ Interaction: Planting Geometry X Varieties } \\
\hline SEm \pm & & 1.30 & 12.1 & 0.16 & 6.54 & 54.09 \\
\hline CD at $5 \%$ & & NS & NS & NS & NS & NS \\
\hline
\end{tabular}


Genotypes play an important role in determining the yield of a crop. The potential yield of genotypes within the genetic limit is set by the environment provided. Among genotypes DCS-99 produced more number of boll per plant (14.68), more boll weight (3.21 $\mathrm{g} \mathrm{boll}^{-1}$ ) and higher seed cotton yield (1383 kg $\mathrm{ha}^{-1}$ ) compared to other genotypes. The probable reason might be the variation in the genetic constitution of the variety which has responded better in harvesting the maximum bolls and good boll weight. These results were in conformity with the finding of Gadade et al., (2015). The interaction effect between planting geometry and genotypes with respect to yield and yield components found to be non- significant

From the study it can be concluded that genotypes and plant density significantly influenced the performance of different cotton genotypes on growth, yield attributes and economics. It was observed that planting geometry of $45 \times 10 \mathrm{~cm}$ resulted in higher seed cotton yield and genotype DSC-99 produced significantly better growth parameters and higher seed cotton yield.

\section{References}

Anonymous, 2017, All India Coordinated Crop Improvement Project on cotton. Annu. Rep., 2015-2016

Bhalerao, P.D., Gawande, P.R., Ghatol, P.U. Andpatil, B.R., 2008, Performance of Bt cotton hybrids for various spacing under rainfed condition. Agric. Sci. Digest. 28 (1): 54- 56.

Gadade, G.D., Gokhale, D.N. and Chavan, A. S., 2015, Performance of hirsutum cotton genotypes to different fertilizer levels under high density planting system. J. Cotton Res. Dev., 29(1): 4547.

Ganvir. S., Ghanbahadur, M. and Kharhkharte, V.K., 2013. Response of hirsutum cotton to high plant density, fertilizers and moisture conservation. Ann. Plant Physio., 27 (1): 33-37.

Gomez, K. A. and Gomez, A.A., 1984, Statistical Procedures for Agriculture Research, 2nd Ed. John Willey and Sons, New York, p. 154.

Jaffar Basha, S., Aruna, E., Sitharama Sarma, and Rama Reddy, 2017, Standardization of Nutrient Management for Cotton (Gossypium arboreum L.) Genotypes under High Density Planting System (HDPS). Int. J. Pure App. Biosci. 5 (6): 1251-1253

Pawar, S. U., Gite, A.N., Bhosle, G.P. and Suryavanshi, S. B. 2010. Effect of fertilizer level and plant densities on yield, gross and net monetary returns of Bt cotton hybrid. J. Cotton Res. Dev. 24(2): 182-185.

Sisodia, R.I. and Khamparia, S.K., 2007, American cotton varieties as influenced by plant densities and fertility levels under rainfed condition. J. Cotton Res. Dev., 21(1): 35-40.

\section{How to cite this article:}

Shashi Kumar, C. and Ramachandra, C. 2019. Growth and Yield of Cotton as Influenced by Planting Geometry and Genotypes under High Density Planting System. Int.J.Curr.Microbiol.App.Sci. 8(05): 2073-2077. doi: https://doi.org/10.20546/ijcmas.2019.805.241 